\title{
Technological Learning in the Accumulation of Technological Capabilities: A Study of the Automotive Industry in Mexico
}

\author{
Blanca Cecilia Salazar Hernandez, PhD \\ Jessica Mendoza Moheno, PhD \\ Martin Aubert Hernandez Calzada, PhD \\ Universidad Autónoma del Estado de Hidalgo
}

Doi: 10.19044/esj.2017.v13n28p487 URL:http://dx.doi.org/10.19044/esj.2017.v13n28p487

\begin{abstract}
This paper will analyze the use of technological learning mechanisms in automotive industry companies located in the central part of Mexico -in the states of Guanajuato, Hidalgo and Queretaro. It will also analyze their impact in the accumulation of technological capabilities. It will explain which mechanisms were used according to the size of these companies. The analysis will conclude that micro-companies face serious limitations in this regard, while medium-size and large companies make better use of the different mechanisms for technological learning which can be seen in the innovation of these businesses.
\end{abstract}

Keywords: Technological learning, technological capability and automotive industry.

\section{Introduction:}

The change in the economic model has generated new trends in the organization of the production, technology and management of businesses, thus encouraging the search of new sources for a competitive advantage. It has been proved that resources such as knowledge, nuclear and dynamic competencies based on intangibles are more valuable that labor and capital as they induce companies to build and accumulate capabilities (De Gortari, 2007); this is why that the accumulation of technological capability is a determining factor for the permanence and development of companies, therefore the potential to learn and create knowledge is fundamental to respond to the challenges presented by the environment (Arias, 2003). 
The automotive and auto-parts ${ }^{8}$ are the more dynamic and competitive sub-sectors in Mexico: aspects such as geographic location, the low level in salaries, trade agreements, and supply network, among others, have been decisive in its evolution and development (Garfias and Martin, 2015). The figures from ProMéxico ${ }^{9}$ in 2014 show that the automotive industry has seen growth, both in the domestic market and in exports and production, en 2014. It currently represents 3\% of the national gross domestic product (GDP) and 17\% of the GDP of the manufacturing sector. From 2006 to $2014,10 \%$ of the direct cumulative foreign investment was attracted by these sub-sectors (ProMéxico, 2015).

However, the dynamics of the industry itself requires companies to maintain high quality standards, a continuous improvement process, and constant innovation in processes and products, hence the accumulation of technological capabilities is critical for permanence and development. In this sense, the accumulation of technological capability must be an intentional and planned process, consequently it is important to identify the practices that propel learning and accumulation, identifying the mechanisms that contribute to this process.

This study is organized in five sections, after the introduction, in section two, the theoretical aspects related to technological learning are described as well as the accumulation of capabilities, base of the study. In the third section, the methodology used is documented, while section four integrates the results and discusses the use of the technological learning mechanisms that the companies studied use, finally section five reports the conclusions.

\section{Technological learning: a theoretical approach}

Technological capabilities are inherent to learning, according to Jasso and Ortega (2007: 70-71), "learning and building technological capability at the company level means a dynamic process of obtaining and building internal capabilities and using the knowledge available from other companies and institutions. The processes of building technological capabilities depend, therefore, on a set of factors related to a flow of knowledge within the company and between the company and the context in which it competes. "

Learning in a business is a key factor for its development; it usually has positive effects and is nourished by all kinds of organizational experiences. Generally it occurs through all the activities of the company and

\footnotetext{
${ }^{8}$ According to the North American Industry Classification System (NAICS), the automotive and auto-parts industry is grouped under sub-sector 336 dedicated to the manufacture of transport equipment.

${ }_{9}$ ProMéxico: federal government agency in charge of promoting exports and attracting strategic investment (ProMéxico, 2015).
} 
implies the construction, complementation and organization of the knowledge and the routines of the company (Dodgson, 1993), which involve internal and external agents such as: clients, suppliers, government agencies and other stakeholders. In this sense, it is assumed that the processes of learning and accumulation of knowledge are decisive in the construction of technological capabilities (Torres, 2006: 13; Vera-Cruz, 2004: 36).

Some authors, such as Kim (1997: 6), define technological learning as the "dynamic process for acquiring technological capabilities", while Bell \& Pavitt (1997) identify it as synonymous with technological accumulation. In general, technological learning is not a natural or involuntary process, it is rather intentional and conscious, of a gradual and collective nature, influenced by different internal and external aspects; where investment and deliberate strategies are required (Bell, 1984; Vera-Cruz, 2004), although it is important to note that the simplest forms of learning are passive, without charge and even automatic (Marcelle, 2004).

At the micro level, Bell \& Pavitt (1997) argue that the main characteristics that contribute to technological accumulation in firms are: input resources, tacit and explicit knowledge, the components associated with learning from specific experiences in the development and operation of production systems, intercompany links and networks, discontinuities in technical change, human capital, complementarity between imported technology and local technological accumulation. They also emphasize that the structure of the market and its pressures, government policies aimed at education, training, research, the development of academic research capacities, intervention policies and technological discontinuities, complementarity between institutions and businesses, as well as financial and administrative institutions, are critical for technological learning and therefore for the accumulation of capability.

In this sense, Lall (1982: 170) identifies as "agents of learning: the production engineers, skilled workers, design engineers, component suppliers, consultants, engineering architects, independent research and development institutes, and so on", excluding non-technical elements such as administrative and financial staff. He also refers to other aspects as factors that favor learning processes such as: the size of the company, access to market competencies, the organizational and managerial capacity of the company, ability to change structures and absorb new methods and technologies, as well as access to external technical and support information. In other words, technological learning is influenced by different internal and external factors.

In this regard, Bell (1984) warns us about the passive and active forms of learning. In terms of passive learning, it is assumed that these are mechanisms derived from the productive activities of the company in its 
most basic forms, which are characterized for being automatic and with no cost.

As for the mechanisms of active learning, these are related to intentional aspects to which resources must be allocated, that must be planned, professionalized and institutionalized, so that their impact on the accumulation of capacities is greater. Figure 1 shows the learning mechanisms that authors like Lall (1982); Bell (1984) and Marcelle (2004) have considered as decisive.

Figure 1. Technological learning mechanism

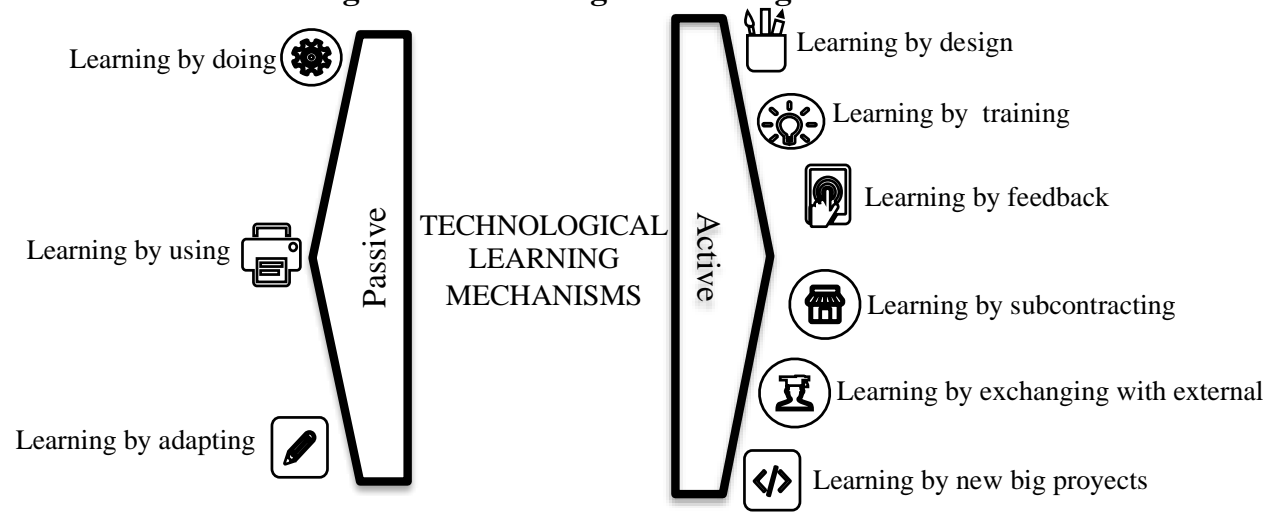

Source: compiled by author base Lall (1982), Bell (1984), Marcelle (2004) and Salazar

(2017)

\section{Methodology}

The article arises from a research project at the regional level that seeks to study the technological capabilities of the automotive industry in the states of Queretaro, Guanajuato and Hidalgo in Mexico. The study follows a quantitative methodological, transversal and descriptive strategy.

The sample ${ }^{10}$ was selected through a stratified random sampling, taking into consideration three branches of the automotive industry, 3361 manufacture of cars and trucks, 3362 manufacture of bodies and trailers and 3363 manufacture of parts for motor vehicles, for which data from the National Statistical Directory of Economic Units (DENUE, 2016) was used, taking into account the states of Guanajuato, Hidalgo and Querétaro. The sample is made up of 48 companies of different size, age, exporting experience and family composition.

The instrument is a questionnaire composed of 40 questions, grouped into 10 sections that seek to investigate topics such as: technological capabilities, internationalization, information technologies, social capital, learning, business strategy, entrepreneurship orientation, organizational culture and performance.

${ }^{10}$ For further study of how the sample was selected, see López, et al (2017). 
We used section 5 of the applied survey to perform the study of the technological learning practices and mechanisms. This section is composed of 14 items that measure the frequency with which each of the mechanisms that promote learning is used, on a scale of 1 to 6 , where 1 refers to "never" and 6 to "always".

An exploratory analysis was carried out and the relationship between the learning mechanisms and the company size was examined, using tools such as contingency tables, the $\mathrm{x} 2$ statistic, as well as the comparison of means. The information processing and statistical analysis was performed using SPSS software version 24.

\section{Technological learning mechanisms in the companies of the automotive cluster in the central area of the Mexican Republic: analysis of results}

As stated in the previous section, the most valuable learning that contributes meaningfully to the accumulation of skills is an active, institutional, planned and intentional learning, although forms of passive learning are useful on a temporary basis. The analysis of practices and technological learning mechanisms used by the companies studied is then performed. Next, we carry out an analysis of the technological learning practices and mechanisms used by the companies studied.

When considering the frequencies "almost always" and "always" as a reflection of the institutional use of some aspects that contribute to technological learning such as: recognition and reward, continuous search by leaders for opportunities to learn, and the sharing of the points of view among the members of the work-team, we observed that these aspects were favored by more than half of the companies studied, as well as the aspects related to the interaction of those work teams, when presenting their points of view during discussion and information sessions (53\%) and the recognition to employees by their initiative when implementing changes $(53 \%)$.

In the same sense, it can be observed that $49 \%$ of companies sustain that leaders are constantly seeking opportunities to learn. The aspect practiced to a lesser extent is that of rewarding people for learning (38\%), which would surely close the virtuous circle of learning in the organization (Table 1). 
Table 1. Aspects that strengthen technological learning that were used

\begin{tabular}{|c|c|c|c|c|c|}
\hline Frequency & $\begin{array}{c}\text { People } \\
\text { are } \\
\text { rewarded } \\
\text { for } \\
\text { learning } \\
(\boldsymbol{\%})\end{array}$ & $\begin{array}{c}\text { Time is spent } \\
\text { to build trust } \\
\text { between the } \\
\text { members } \\
(\boldsymbol{\%})\end{array}$ & $\begin{array}{c}\text { Groups and teams } \\
\text { review their opinions as } \\
\text { a result of group } \\
\text { discussions or } \\
\text { information gatherings } \\
(\boldsymbol{\%})\end{array}$ & $\begin{array}{c}\text { Employees } \\
\text { who show } \\
\text { initiative are } \\
\text { rewarded } \\
(\boldsymbol{\%})\end{array}$ & $\begin{array}{c}\text { Leaders } \\
\text { continually seek } \\
\text { opportunities to } \\
\text { learn } \\
(\boldsymbol{\%})\end{array}$ \\
\hline Never & 6 & 11 & 19 & 6 & 19 \\
\hline Rarely & 34 & 11 & 9 & 19 & 6 \\
\hline Sometimes & 15 & 19 & 11 & 4 & 9 \\
\hline Often & 6 & 17 & 9 & 17 & 17 \\
\hline Almost always & 19 & 30 & 28 & 28 & 26 \\
\hline Always & 19 & 13 & 26 & 26 & 23 \\
\hline
\end{tabular}

Source: own elaboration with data from the analysis of the database resulting from the field research.

In regard to the learning mechanisms used, it can be noted that in 62 percent of the companies, the most basic learning was used. This basic learning is based on operational experience and in carrying out the different tasks and its usual characteristics are: being passive, automatic, and free of charge. It is important to emphasize that more than half of the companies (58\%) sustain that they always or almost always make the lessons learned available to their workers; this mechanism transform the socialization of knowledge from individual to organizational learning (Table 2). On the other hand, it was detected that other aspects such as external links to the solution of problems $(38 \%)$ and the detection of technical problems for the design and implementation of changes (36\%) are the least used, this situation, in a sense, reflects the need to implement intentional and active learning mechanisms, which will contribute considerably and without a doubt to the accumulation of technological capabilities.

Table 2. Technological learning mechanisms used (1)

\begin{tabular}{|l|c|c|c|c|c|}
\hline Frequency & $\begin{array}{c}\text { The } \\
\text { lessons } \\
\text { learned } \\
\text { are made } \\
\text { available } \\
\text { to all } \\
\text { employee } \\
\mathbf{s}(\boldsymbol{\%})\end{array}$ & $\begin{array}{c}\text { Work is done } \\
\text { with the } \\
\text { external } \\
\text { community } \\
\text { to solve their } \\
\text { mutual needs } \\
\text { jointly } \\
(\boldsymbol{\%})\end{array}$ & $\begin{array}{c}\text { Work is done to } \\
\text { improve the } \\
\text { company's } \\
\text { operating and } \\
\text { production } \\
\text { processes from the } \\
\text { failures identified } \\
\text { day by day } \\
(\boldsymbol{\%})\end{array}$ & $\begin{array}{c}\text { Collaborators } \\
\text { implement } \\
\text { small changes } \\
\text { in processes } \\
\text { that will } \\
\text { contribute to } \\
\text { performance } \\
\text { improvement } \\
(\boldsymbol{\%})\end{array}$ & $\begin{array}{c}\text { Changes are } \\
\text { implemented for } \\
\text { improvement as a } \\
\text { result of the } \\
\text { identification of } \\
\text { technical } \\
\text { problems in the } \\
\text { processes, } \\
\text { (\%) }\end{array}$ \\
\hline Never & 19 & 26 & 17 & 15 & 15 \\
\hline Rarely & 9 & 11 & 4 & 19 & 17 \\
\hline Sometimes & 4 & 15 & 4 & 4 & 9 \\
\hline Often & 11 & 11 & 13 & 23 & 23 \\
\hline Almost always & 36 & 28 & 23 & 15 & 17 \\
\hline Always & 21 & 11 & 38 & 25 & 19 \\
\hline
\end{tabular}

Source: own elaboration with data from the analysis of the database resulting from the field research. 
When studying the behavior of companies in regard to active and intentional learning mechanisms that require of planning and investment, the recruitment of trained and specialized professionals $(60 \%)$ stands out. This has a positive effect on technological learning, given that the organizations obtain knowledge from the exterior, which is then added to their learning processes. While it is true that the data reflected a limited relationship with the exterior, when we asked whether there was a constant search for suppliers of technology, components and technological advances, new raw materials and emerging markets, $47 \%$ of companies said that almost always or always, did they do it, reflecting the interest and actions concerning technological research (Table 3).

Feedback is a learning mechanism that once institutionalized and formalized results in an important source of generation of knowledge and technical change, in this respect it has been recognized that, while $44 \%$ of companies affirm that they always or almost always perform feedback, 30\% accepts that they never or almost never do it. Similarly, only $44 \%$ of the firms recognize that training programs have contributed to technical change in comparison with a $27 \%$ that reject the relationship between training, efficiency and technical change (Table 3).

Table 3. Technological learning mechanisms used (2)

\begin{tabular}{|l|c|c|c|c|}
\hline Frequency & $\begin{array}{c}\text { Has } \\
\text { established a } \\
\text { feedback } \\
\text { system (\%) }\end{array}$ & $\begin{array}{c}\text { Training } \\
\text { programs } \\
\text { have impacted } \\
\text { on efficiency } \\
\text { and technical } \\
\text { change } \\
(\boldsymbol{\%})\end{array}$ & $\begin{array}{c}\text { The hired } \\
\text { personnel are } \\
\text { trained } \\
\text { professionals, } \\
\text { specialized in } \\
\text { their area (\%) }\end{array}$ & $\begin{array}{c}\text { Maintains a } \\
\text { constant search } \\
\text { for suppliers of } \\
\text { technology, } \\
\text { components and } \\
\text { technological } \\
\text { advances, new } \\
\text { raw materials } \\
\text { and emerging } \\
\text { markets (\%) }\end{array}$ \\
\hline Never & 28 & 27 & 6 & 15 \\
\hline Rarely & 2 & 2 & 4 & 13 \\
\hline Sometimes & 9 & 8 & 15 & 11 \\
\hline Often & 17 & 19 & 15 & 15 \\
\hline $\begin{array}{l}\text { Almost } \\
\text { always }\end{array}$ & 23 & 19 & 25 & 31 \\
\hline Always & 21 & 25 & 35 & 15 \\
\hline
\end{tabular}

Source: own elaboration with data from the analysis of the database resulting from the field research.

It is important mentioning that strengthening this type of mechanisms contributes to the promotion of technological capacities based on learning at the individual and organizational levels. 
Table 4. Technological learning mechanisms used by companies according to their size

\begin{tabular}{|c|c|c|c|c|c|}
\hline Size of company & Micro & Small & Medium & Large & Sig. \\
\hline People are rewarded for learning & 2 & 3 & 4 & 4 & 0.05 \\
\hline $\begin{array}{l}\text { Time is spent to build trust } \\
\text { between the members }\end{array}$ & 2 & 4 & 5 & 4 & 000 \\
\hline $\begin{array}{l}\text { Groups and teams review their } \\
\text { opinions as a result of group } \\
\text { discussions or information } \\
\text { gatherings }\end{array}$ & 2 & 3 & 5 & 5 & 000 \\
\hline $\begin{array}{l}\text { Employees who show initiative are } \\
\text { rewarded }\end{array}$ & 2 & 3 & 5 & 5 & 0.002 \\
\hline $\begin{array}{l}\text { Leaders continually seek } \\
\text { opportunities to learn }\end{array}$ & 3 & 4 & 5 & 4 & 0.006 \\
\hline $\begin{array}{l}\text { The lessons learned are made } \\
\text { available to all employees }\end{array}$ & 2 & 3 & 4 & 4 & 0.008 \\
\hline $\begin{array}{l}\text { Work is done with the external } \\
\text { community to solve their mutual } \\
\text { needs jointly }\end{array}$ & 2 & 4 & 5 & 5 & 000 \\
\hline $\begin{array}{l}\text { Work is done to improve the } \\
\text { company's operating and } \\
\text { production processes from the } \\
\text { failures identified day by day }\end{array}$ & 2 & 4 & 5 & 5 & 000 \\
\hline $\begin{array}{l}\text { Collaborators implement small } \\
\text { changes in processes that will } \\
\text { contribute to performance } \\
\text { improvement }\end{array}$ & 2 & 4 & 5 & 4 & 0.001 \\
\hline $\begin{array}{l}\text { Changes are implemented for } \\
\text { improvement as a result of the } \\
\text { identification of technical } \\
\text { problems in the processes, }\end{array}$ & 2 & 3 & 5 & 4 & 000 \\
\hline Has established a feedback system & 2 & 3 & 5 & 5 & 000 \\
\hline $\begin{array}{l}\text { Training programs have impacted } \\
\text { on efficiency and technical change }\end{array}$ & 2 & 3 & 5 & 4 & 000 \\
\hline $\begin{array}{l}\text { The hired personnel are trained } \\
\text { professionals, specialized in their } \\
\text { area }\end{array}$ & 4 & 6 & 5 & 4 & 0.011 \\
\hline $\begin{array}{l}\text { Maintains a constant search for } \\
\text { suppliers of technology, } \\
\text { components and technological } \\
\text { advances, new raw materials and } \\
\text { emerging markets }\end{array}$ & 2 & 4 & 5 & 5 & 000 \\
\hline
\end{tabular}

Source: Own elaboration from data from the survey. Item Rating (1) Never and (6) Always

In regard to the level of use that organizations give to technological learning mechanisms according to their size, Table 4 shows statistically significant differences in the mean comparative, that is, the greater the company is in size, the greater the frequency with which the technological 
learning mechanisms are applied, specifically for this case, we noticed the best levels of use occur in medium-sized companies.

Microenterprises in particular rarely apply passive or active learning mechanisms, with the exception of the hiring of specialized and professionally trained people, a practice they report is common. In the case of small enterprises, the aspects that have been used repeatedly are those related to building trust, recognizing people's initiative, improving their operational and production processes based on the failures identified day by day, the implementation of small changes in the processes that contribute to the improvement of performance, as well as the constant search of suppliers of technology, components and technological advances, new raw materials and emerging markets. The hiring of professionally trained and specialized personnel stands out as a mechanism that is used all the time.

In contrast to micro and small enterprises, medium-sized firms reflect better performance in the use of learning mechanisms; In fact, most of them mentioned that it is something they almost always do. Specifically, they use those related to improving their operating and production processes based on the failures identified on a daily basis, training programs that impact on efficiency and technical change, as well as the hiring of trained and specialized professionals in their area, which stand out as institutionalized mechanisms.

In the case of large companies, there is also a tendency to formalize a significant number of those mechanisms, such as: improving their operational and production processes based on the failures identified on a day-to-day basis, the institutionalization of the feedback system, making available to all employees the lessons learned and to maintain the constant search of suppliers of technology, components and technological advances, new raw materials and emerging markets. It should be noted that mediumsized companies are the ones with the best results in terms of the use of institutionalized technological learning mechanisms.

When analyzing each of the aspects used as learning tools based on the size of a company, it is usually observed that micro and small businesses have serious limitations in the use and application of technological learning mechanisms. It is also important to note that there are statistically significant differences according to the size of the company in most of the mechanisms. 
Table 5. Percentage of companies that use passive learning mechanisms

\begin{tabular}{|c|c|c|c|c|}
\hline Frequency & Micro (\%) & Small (\%) & $\begin{array}{c}\text { Medium } \\
(\%)\end{array}$ & $\begin{array}{c}\text { Large } \\
(\%)\end{array}$ \\
\hline Never & $63.60 \%$ & & & $7.70 \%$ \\
\hline Rarely & $9.10 \%$ & $14.30 \%$ & & \\
\hline Sometimes & & $28.60 \%$ & & \\
\hline Often & & $14.30 \%$ & $15.40 \%$ & $7.70 \%$ \\
\hline Almost always & $9.10 \%$ & & $30.80 \%$ & $46.20 \%$ \\
\hline Always & $18.20 \%$ & $42.90 \%$ & $53.80 \%$ & $38.50 \%$ \\
\hline & $100 \%$ & $100 \%$ & $100 \%$ & $100 \%$ \\
\hline
\end{tabular}

Collaborators implement small changes in processes that will contribute to performance improvement

\begin{tabular}{|c|c|c|c|c|c|}
\hline Never & $54.50 \%$ & & & $7.70 \%$ & \multirow[t]{7}{*}{0.001} \\
\hline Rarely & $27.30 \%$ & $57.10 \%$ & & $7.70 \%$ & \\
\hline Sometimes & & & $15.40 \%$ & & \\
\hline Often & & & $30.80 \%$ & $30.80 \%$ & \\
\hline Almost always & $9.10 \%$ & & $23.10 \%$ & $23.10 \%$ & \\
\hline \multirow[t]{2}{*}{ Always } & $9.10 \%$ & $42.90 \%$ & $30.80 \%$ & $30.80 \%$ & \\
\hline & $100 \%$ & $100 \%$ & $100 \%$ & $100 \%$ & \\
\hline
\end{tabular}

Changes are implemented for improvement as a result of the identification of technical problems in the processes

\begin{tabular}{|l|r|r|r|r|r|}
\hline Never & $54.50 \%$ & & & $7.70 \%$ & \multirow{2}{*}{0.006} \\
\cline { 1 - 4 } Rarely & $18.20 \%$ & $57.10 \%$ & $7.70 \%$ & $7.70 \%$ \\
\cline { 1 - 4 } Sometimes & $9.10 \%$ & & $7.70 \%$ & $7.70 \%$ \\
\hline Often & $9.10 \%$ & $14.30 \%$ & $23.10 \%$ & $30.80 \%$ \\
\hline Almost always & $9.10 \%$ & $14.30 \%$ & $38.50 \%$ & $7.70 \%$ \\
\hline Always & & $14.30 \%$ & $23.10 \%$ & $38.50 \%$ \\
\cline { 1 - 4 } & $100 \%$ & $100 \%$ & $100 \%$ & $100 \%$ & \\
\cline { 1 - 3 } & & &
\end{tabular}

Source: Own elaboration from data from the survey.

Table 5 addresses the aspects of learning by doing and operating, showing that $42.90 \%$ of the small enterprises, $84.6 \%$ of the medium enterprises and $84.7 \%$ of the larger ones, maintain their efforts to improve their operating and production processes from the failures encountered day by day, always or almost always. As for the changes made at the initiative of the workers, $53.90 \%$ of the medium and large companies claim to use it, while only $42.90 \%$ of the small companies do so. It should be mentioned that micro enterprises recognize in a greater percentage, the lack of use of these passive learning mechanisms, which in some cases are with no cost and usually automatic.

In regard to the practices used to identify technical problems during the processes and in which changes to improve the performance through technological investment projects are designed and implemented, we 
observed that $61 \%$ of medium size businesses use them.

Table 6. Percentage of companies using active learning mechanisms (1)

\begin{tabular}{|c|c|c|c|c|c|}
\hline \multicolumn{6}{|c|}{ The lessons learned are made available to all employees } \\
\hline Frequency & Micro (\%) & Small $(\%)$ & Medium (\%) & Large $(\%)$ & Sig. \\
\hline Never & $54.50 \%$ & $14.30 \%$ & $7.70 \%$ & $7.70 \%$ & \multirow[t]{7}{*}{0.013} \\
\hline Rarely & $18.20 \%$ & $28.60 \%$ & & & \\
\hline Sometimes & & & $15.40 \%$ & & \\
\hline Often & & $28.60 \%$ & & $15.40 \%$ & \\
\hline Almost always & $18.20 \%$ & $14.30 \%$ & $46.20 \%$ & $46.20 \%$ & \\
\hline \multirow[t]{2}{*}{ Always } & $9.10 \%$ & $14.30 \%$ & $30.80 \%$ & $30.80 \%$ & \\
\hline & $100 \%$ & $100 \%$ & $100 \%$ & $100 \%$ & \\
\hline \multicolumn{6}{|c|}{ Work is done with the external community to solve their mutual needs jointly } \\
\hline Never & $72.70 \%$ & $28.60 \%$ & $7.70 \%$ & $7.70 \%$ & \multirow[t]{7}{*}{0.022} \\
\hline Rarely & & $28.60 \%$ & $7.70 \%$ & $15.40 \%$ & \\
\hline Sometimes & & & $15.40 \%$ & $23.10 \%$ & \\
\hline Often & $9.10 \%$ & $28.60 \%$ & $15.40 \%$ & & \\
\hline Almost always & $18.20 \%$ & $14.30 \%$ & $38.50 \%$ & $30.80 \%$ & \\
\hline \multirow[t]{2}{*}{ Always } & & & $15.40 \%$ & $23.10 \%$ & \\
\hline & $100 \%$ & $100 \%$ & $100 \%$ & $100 \%$ & \\
\hline \multicolumn{6}{|c|}{ Leaders continually seek opportunities to learn } \\
\hline Never & $72.70 \%$ & & & $7.70 \%$ & \multirow[t]{7}{*}{000} \\
\hline Rarely & & $42.90 \%$ & & & \\
\hline Sometimes & & & & $15.40 \%$ & \\
\hline Often & & $28.60 \%$ & $23.10 \%$ & $23.10 \%$ & \\
\hline Almost always & $18.20 \%$ & & $53.80 \%$ & $15.40 \%$ & \\
\hline \multirow[t]{2}{*}{ Always } & $9.10 \%$ & $28.60 \%$ & $23.10 \%$ & $38.50 \%$ & \\
\hline & $100 \%$ & $100 \%$ & $100 \%$ & $100 \%$ & \\
\hline
\end{tabular}

Source: Own elaboration from data from the survey.

Table 6 presents the percentage of companies that make use of active learning mechanisms, stressing that $77 \%$ of the medium and large companies share the lessons learned with their workers, while more than half of those firms $(53.90 \%)$ claim to have relationships with the outside community to jointly solve their mutual needs.

On the other hand, in $76.90 \%$ of the medium size companies and $53.90 \%$ of the large ones, the leaders continuously seek new opportunities to learn, which reflects the interest of the enterprises to create virtuous processes that will boost the accumulation of technological capacities. 
Table 7. Percentage of companies using active learning mechanisms (2)

\begin{tabular}{|c|c|c|c|c|c|}
\hline \multicolumn{6}{|c|}{ Has established a feedback system } \\
\hline Frecuency & Micro (\%) & Small (\%) & $\begin{array}{l}\text { Medium } \\
(\%)\end{array}$ & Large $(\%)$ & Sig. \\
\hline Never & $81.80 \%$ & $42.90 \%$ & & $7.70 \%$ & \multirow[t]{7}{*}{0.004} \\
\hline Rarely & & $14.30 \%$ & & & \\
\hline Sometimes & & & $7.70 \%$ & $7.70 \%$ & \\
\hline Often & & $14.30 \%$ & $38.50 \%$ & $15.40 \%$ & \\
\hline Almost always & $18.20 \%$ & $14.30 \%$ & $23.10 \%$ & $30.80 \%$ & \\
\hline \multirow[t]{2}{*}{ Always } & & $14.30 \%$ & $30.80 \%$ & $38.50 \%$ & \\
\hline & $100 \%$ & $100 \%$ & $100 \%$ & $100 \%$ & \\
\hline \multicolumn{6}{|c|}{ Training programs have impacted on efficiency and technical change } \\
\hline Never & $81.80 \%$ & $42.90 \%$ & & $7.70 \%$ & \multirow[t]{7}{*}{0.001} \\
\hline Rarely & & $14.30 \%$ & & & \\
\hline Sometimes & & & & $7.70 \%$ & \\
\hline Often & $9.10 \%$ & & $23.10 \%$ & $38.50 \%$ & \\
\hline Almost always & $9.10 \%$ & & $38.50 \%$ & $15.40 \%$ & \\
\hline \multirow[t]{2}{*}{ Always } & & $42.90 \%$ & $38.50 \%$ & $30.80 \%$ & \\
\hline & $100 \%$ & $100 \%$ & $100 \%$ & $100 \%$ & \\
\hline \multicolumn{6}{|c|}{$\begin{array}{l}\text { Maintains a constant search for suppliers of technology, components and } \\
\text { technological advances, new raw materials and emerging markets }\end{array}$} \\
\hline Never & $54.50 \%$ & & & $7.70 \%$ & \multirow[t]{7}{*}{0.003} \\
\hline Rarely & $18.20 \%$ & $28.60 \%$ & $15.40 \%$ & & \\
\hline Sometimes & $18.20 \%$ & $28.60 \%$ & & & \\
\hline Often & & $14.30 \%$ & $15.40 \%$ & $30.80 \%$ & \\
\hline Almost always & & & $15.40 \%$ & $23.10 \%$ & \\
\hline \multirow[t]{2}{*}{ Always } & $9.10 \%$ & $28.60 \%$ & $53.80 \%$ & $38.50 \%$ & \\
\hline & $100 \%$ & $100 \%$ & $100 \%$ & $100 \%$ & \\
\hline
\end{tabular}

Source: Own elaboration from data from the survey.

In this same sense, $69.30 \%$ of large companies and $53.90 \%$ of medium companies have implemented an institutionalized feedback system, while only $28.60 \%$ of small firms claim to apply it. On the other hand, both the training program aimed at improving staff efficiency, plant maintenance and the generation of technical changes in processes are used in greater proportion by medium-sized enterprises (77\%), while only slightly more than $40 \%$ of the large (46.20\%) and small (42.90\%) firms do it.

One of the aspects that encourages learning significantly is technological surveillance, through which a constant search for technology suppliers, components and technological advances, new raw materials and emerging markets is maintained; an aspect that is almost always or always used by $69.20 \%$ of the large companies and for just $61.60 \%$ of the medium companies (table 7).

In order to explain the importance that the use and application of the technological learning mechanisms have in the accumulation of technological capabilities, it is worth mentioning that the level of 
accumulation is reflected in innovation in processes, products, organization and marketing (OECD, 2006). In this sense, the analysis shows that while micro and small enterprises claim to have on average two new product innovations, medium-sized companies have reached eight, and large firms slightly more than thirteen, reflecting a more advanced level of capacity in technological learning. That is why it is important to emphasize that, to the extent that companies make institutional use of technological learning mechanisms, it will result in an increase in the accumulation of capacities and therefore in innovation, which will positively impact on their development and permanence.

Graph 1. Number of innovations on average

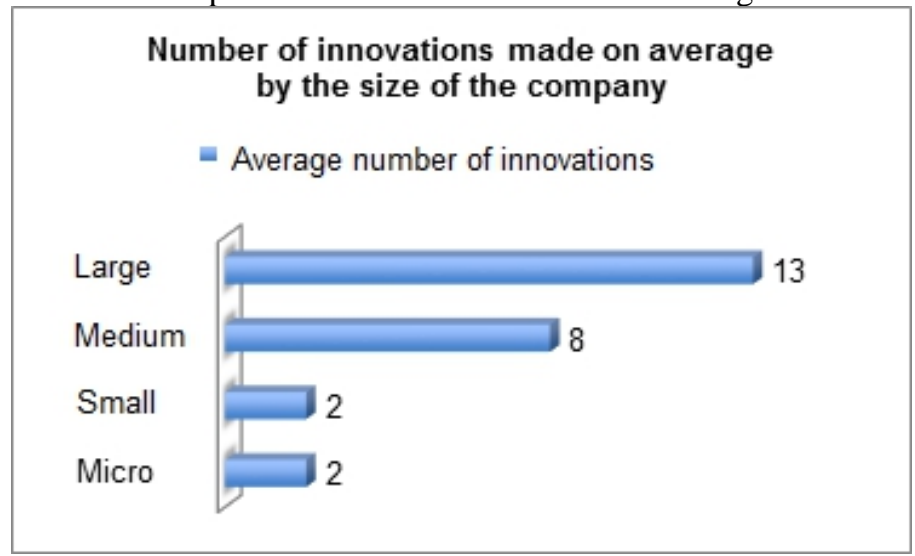

Source: Own elaboration from data from the survey.

\section{Conclusion}

At present, intangible resources such as knowledge and dynamic competencies are more valuable than work and capital, so the ability to learn and create knowledge is fundamental for the permanence and development of businesses. The study of companies of the automotive sector and auto parts in the central zone of the country allows us to identify the learning mechanisms that they use according to the type of company, classified by size.

As expected, the larger the company is, the greater the number of learning mechanisms it adopts, even though in this study it was found that medium size companies are the ones that have the best results in the use of formalized learning mechanisms.

In general, the mechanisms used the most by the companies studied are those related to improve the operative and production processes starting from the failures detected day by day $(62 \%)$, the hiring of trained and specialized professionals $(60 \%)$, as well as making available to the workers the lessons learned $(58 \%)$. Also, more than half of the firms favor the interaction of 
work teams by exchanging points of view during discussion and information sessions (53\%) and acknowledging employees for their initiative (53\%).

Specifically, microenterprises seldom apply passive or active learning mechanisms; the processes used in a greater proportion are those that make available to all employees the lessons learned $(27.30 \%)$, and the search by the leaders of new learning opportunities (27.30\%).

On the other hand, $42.90 \%$ of small companies use and implement mechanisms oriented to search for improvement of their operating and production processes from the failures identified day by day, the implementation of small changes in the processes that contribute to the improved performance at the initiative of suppliers, as well as improving staff efficiency, plant maintenance and technical changes in processes with training programs.

Contrary to the above, $77 \%$ of medium and large companies share the lessons learned with their workers, while more than half of them $(53.90 \%)$ affirm that they have relations with the outside community to jointly solve their mutual needs. On the other hand, leaders are continually looking for opportunities to learn, $76.90 \%$ in medium-sized firms and $53.90 \%$ in large firms.

In this same sense, $84.6 \%$ of the medium-sized companies and $84.7 \%$ of the large companies maintain their efforts to improve their operating and production processes based on the failures identified on a day to day basis.

On the other hand, $69.30 \%$ of large companies and $53.90 \%$ of medium firms have implemented an institutionalized feedback system, while a training program aimed at improving staff efficiency, plant maintenance and a generation of technical changes in processes is implemented in greater proportion by medium companies (77\%). Finally, the analysis shows that $69.20 \%$ of large companies and $61.60 \%$ of medium-sized companies maintain a constant search for suppliers of technology, components and technological advances, new raw materials and emerging markets.

It is worth mentioning that the use and application of technological learning mechanisms show their usefulness when observing that the companies that implement them almost always or always have come up, on average, with more innovations which are then reflected in new products or improvements to the ones that already exist.

\section{References:}

1. Arias, A. (2003). Mecanismos de aprendizaje y capacidades tecnológicas: el caso de una empresa del sector curtidor. En J. Aboites, \& G. Dutrénit, Innovación, aprendizaje y creación de las capacidades tecnológicas. México: Miguel Ángel Porrúa. 
2. Bell, M. (1984), "Learning and the Accumulation of Industrial Capacity in Developing Countries", in K. King and M. Fransman (Eds), Technological Capability in the Third World, London: Macmillan.

3. Bell, M., \& Pavitt, K. (1997). "Technological accumulation and industrial growth: contrasts between developed and developing countries", in Archibugi, D., and Michie, J. (Eds), Technology, globalisation and economic performance. Cambridge University Press, 83137, 83-137.

4. De Gortari, G. (2007). "La nueva administración del conocimiento. El papel central de las áreas tecnológicas en las grandes empresas mexicanas", en Dutrénit, G., y Villavicencio, D. (Eds), Globalización, acumulación de capacidades e innovación: Los desafios para las empresas, localidades y países. Fondo De Cultura Economica USA.

5. Dodgson, M. (1993). Organizational learning: a review of some literatures. Organization studies , 14 (3), 375-394.

6. Garfias, J., \& Martín, M. (2015). La industria automotriz y su relevancia en la economía. Elementos 22 (98), 3-9.

7. Hall, R., \& Andriani, P. (1998). Analysing intangible resources and managing knowledge in a supply chain context. European management journal, 16(6), 685-697.

8. Jasso, V., \& Ortega, R. (2007). Acumulación de capacidades tecnológicas locales en un grupo industrial siderúrgico en México. Contaduría y Administración, (223), 69-89.

9. Kim, L. (1997). Imitation to innovation: The dynamics of Korea's technological learning. Boston: Harvard Business Press.

10. Lall, S. (1982). Technological learning in the Third World: some implications of technology exports. En \&. J. J. Stewart, The economics of new technology in developing countries. Westview Press.

11. López, A., Molina, R., Contreras, R., Ríos, M. and López, C. (2017). Capacidades Tecnológicas: impacto en la competitividad empresarial. México: Pearson.

12. Marcelle, G. (2004). Technological Learning. A strategic imperative for firms in the developing world. Massachusetts, USA: Edward Elgar Publishing Limited.

13. Parmar, B.L., Freeman, R.E., Harrison, J.S., Wicks, A.C., Purnell, L. and de Colle, S. (2010). Stakeholder theory: e state of the art. Academy of Management Annals, 3, 403-445. 
14. ProMéxico. (2015). ProMéxico Inversión y Comercio. (ProMéxico, Productor) Recuperado el 10 de Enero de 2016, de Perfil del Sector Automotriz: mim.promexico.gob.mx/wb/mim/auto_perfil_del_sector.

15. Salazar, R. (2017). El diseño organizacional: sustento de las capacidades tecnológicas en empresas del Estado de Hidalgo. Tesis doctoral, UNAM: México.

16. Sánchez, E. F., Peón, J. M. M., \& Ordás, C. J. V. (1998). Los recursos intangibles como factores de competitividad de la empresa. Dirección y organización, (20).

17. Vargas, A. T. (2006). Aprendizaje y construcción de capacidades tecnológicas. Journal of Technology Management \& Innovation, $1(5), 12-24$.

18. Vera-Cruz, A. O. (2004). Cultura de la empresa, aprendizaje y capacidades tecnológicas. El caso de las cerveceras mexicanas, México: UAM/ADIAT/Miguel Angel Porrúa. 